\author{
Jerzy Sierociuk \\ Adam Mickiewicz University in Poznań \\ Institute of Polish Philology \\ ORCID: 0000-0001-9069-6117; e-mail: jasier@amu.edu.pl
}

\title{
The methodological assumptions about research into language of villagers
}

\begin{abstract}
The article presents a presumption that contemporary rural areas are witnesses not only to intense transformations of the inhabitants' living conditions but also very rapid changes to the language spoken by the local communities where the traditionally defined dialects are less and less frequently the major means of communication.

3) The presented research proposal highlights the need for taking into account several premises:

collecting in the field lexical material mainly by focusing attention on a specific subject area;

2) taking into account various social and linguistic parameters at the stage of collecting the material; for the research, select informants who represent various generations as indicated by the informants' years of birth; for the purpose of clarity, five generation intervals have been identified;

3 ) the material, subjected to computer processing, should be accompanied by particulars including a few basic parameters that allow to characterise each element in detail.
\end{abstract}

Key words: dialect, language spoken in rural areas, research methodology.

Abstrakt: Założenia metodologiczne badań języka wsi. W artykule wychodzi się z przeświadczenia, że współczesne wieś jest terenem nie tylko intensywnych przeobrażeń warunków życia jej mieszkańców, lecz także jest to obszar bardzo szybko zachodzących przeobrażeń języka kształtującej ją społeczności, gdzie tradycyjnie pojmowane gwary coraz rzadziej są podstawowym środkiem porozumiewania się. Prezentowana propozycja badawcza akcentuje potrzebę uwzględnienia kilku przesłanek:

1) gromadzenie w terenie materiału leksykalnego głównie poprzez koncentrację uwagi na określonym polu tematycznym;

2) na etapie gromadzenia materiału uwzględniać różne parametry socjolingwistyczne;

3) do badań typować informatorów reprezentujących różne grupy pokoleniowe wyznaczane rokiem urodzenia informatora; dla celów porządkujących przyjmuje się pięć takich przedziałów pokoleniowych;

4) poddawany obróbce komputerowej materiał ma być zaopatrzony w odpowiednią metryczkę zawierająca kilka podstawowych parametrów pozwalających na dokładna charakterystykę każdego z jego elementów.

Słowa kluczowe: gwara, język wsi, metodologia badań.

Contemporary rural areas are witnesses not only to intense transformations of the inhabitants' living conditions but also very rapid changes to the language spoken by the local communities. The traditionally defined dialects are less and less frequently the major means of oral communication, just as the old (basic) farming activities and 
tools are in fact familiar only to the oldest representatives of the contemporary farming population.

In the light of the dynamic linguistic changes coupled with the internal diversity of the language spoken in contemporary rural areas, dialectologists need to consider them in the research plans; this involves changes to research orientations, especially at the stage of field work. However, field explorations are derivatives of general methodological assumptions.

Contemporary dialectology has at its disposal a practically satisfactory description of the territorial distribution of lexical units characteristic of dialects. However, a static approach to these phenomena prevails. Therefore, there is an urgent need if not a requirement to focus on two aspects: observing the processes of linguistic evolution (especially on a lexical level) and a derivative of the above: documenting a relatively complete assortment of the language spoken in contemporary rural areas.

At present we know enough about the dialectal diversity on the phonetic level and - on the basis of selected units - the lexical level; not much is known about the morphological diversity, especially word-forming. However, this is not about a register of morphological elements but predominantly about diversification of processes, word-forming techniques, the processes' dynamics and diversity. Lexical research is not accompanied by theoretical reflection, either; we do not know much about the semantic structure of specific thematic (lexical) areas, their specificity or the territorial diversity of the arrangement of lexical and semantic structures.

Completed as well as currently edited atlases of dialects present material which, to a large extent, belongs to the past. Similarly, the Atlas jezzyka i kultury ludowej Wielkopolski (AJKLW) is now of historical nature. In fact, the field material obtained in the mid-1970s represents a language spoken by a past generation. As a result of the specific selection of the informants recruited from the oldest generation (a large part of the respondents were people born back in the $19^{\text {th }}$ century; in the other cases the date of birth did not exceed 1910) we lose sight of the language spoken by their children, grandchildren and - practically - great grandchildren. However, there is an urgent need to observe linguistic behaviour of the three new generations.

Notably, the need for regular repetition of field research has been postulated at the stage of establishing the Poznań centre of dialectology. L. Zabrocki, an organiser of the Phonographic Archive, presented sound registration of dialects which started in 1948 as follows:

The sound should be recorded with respect to the future phonetic (phonological), vocabulary and syntax analyses. Within ten years, global recording of all the dialects of the Polish language is to be completed in Poland and abroad. The next general recording should take place in twenty five years. Consequently, the Archive will have a recorded picture of the Polish language in intervals of twenty five years (Zabrocki 1948, 516).

Inhabitants of the rural areas in Wielkopolska speak a language different from the one registered in the first recordings; it also varies from the language presented on the maps in the AJKLW. In fact, there are no longer pure, traditional dialects in 
Wielkopolska. It is equally true that we know relatively little about the speed, direction and specificity of the changes to the linguistic environment.

The contemporary organisational and technical solutions allow to prevent this situation. Below I present the methodological assumptions adopted in the course of field research by the team of the Institute of Polish Dialectology of the Poznan University.

The major goal is setting up an archive that would reflect the condition of the linguistic diversity in contemporary rural areas. In the course of obtaining field material, the rules presented in this article have been followed. Let me stress the fact that the collected documentation is intended to be neutral with respect to any methodological concept (and this is one of the major assumptions). This means that the documentation is not collected for the purpose of research according to the assumptions of structuralism, generativism, cognitivism or other methodological orientations. Similarly, it is not our intention to juxtapose a corpus of materials in order to survey phenomena exclusively on a specific level of language description: morphology, lexical or semantic sets. We also have in mind obtaining possibly broad contexts of the cultural entanglement of the specific phenomena and linguistic units ${ }^{1}$. The analyses included in the AJKLW serve as a good point of reference.

This procedure may be referred to in a most general way in the following way: possibly most ample material providing data necessary for a comprehensive and diverse description.

Before I proceed with detailed proposals, let me present some more general assumptions.

In field research, an assumption is made that possibly most extensive thesauruses should be compiled, including also various grammatical forms. We do realise that editing complete dictionaries is practically impossible. Nevertheless, by focusing on selected subject areas, for comparison reasons and to define the internal lexical and semantic structures of the language spoken by inhabitants of selected villages, we hope to obtain sets which would indicate the idiosyncrasy of the organisation of specific sections of the linguistic reality inside various rural populations and in the opposition between the general language and the language spoken in rural areas. We assume to shift the focus from the frequently incidental (in these cases) set of lexical units to comparing closed and holistic sections of specific lexical and semantic structures.

The concept of a thematic area was presented by T. Skubalanka ${ }^{2}$; created on the basis of association, the concept is semantically capacious and can be very extended, including many distinctly marked lexical and semantic areas. By focusing on a specific subject in the course of the research, we enjoy the opportunity of confirming rare units which are also characteristic of a specific generation.

\footnotetext{
1 These ventures are exemplified by, for example, Stownictwo pola tematycznego WIERZENIA I OBRZĘDY $w$ gwarze ... This subject, with a distinct ethno-linguistic bias, enjoys considerable interest of participants of M.A. seminars.

2 In her work dedicated to love-related vocabulary used by J. Słowacki, T. Skubalanka referred to the thematic criterion; she called the resulting arrangement of concepts "a thematic or connotation area"; see (Skubalanka 1966, 16).
} 
Of importance is also the fact that in this research framework, at the stage of field exploration, it is possible to include into the team less experienced members; it is easier to prepare an explorer with respect to the content bearing in mind only a specific section of the rural reality rather than a broad range of thematically diversified issues. Field work is also conducted by students, participants of M.A. seminars ${ }^{3}$ and optional classes.

In the adopted assumptions, an important role is assigned to the generational diversity of the language spoken by inhabitants of contemporary rural areas. It is assumed that the complexity of linguistic behaviour of a specific individual is mainly affected by the time in which his/her linguistic competence was shaped, the time needed to master a linguistic system together with cultural references. For this reason (and also for the purpose of clarity), we focus primarily on the generational affiliation specified by the year of birth. Based on our experience, we have identified the following generational intervals:

I. born before 1920. This generational group is practically no longer represented. This is a generation which developed its linguistic habits at home; it is also a generation whose language (Polish) was not affected by the school. In fact, this generation's language is best documented, presented on the maps of language atlases. When this proposal was being developed, conversations with representatives of that generation were possible and very recommended. At present (an entire generation later), it would be difficult to record a representative of this generational interval in the course of a field exploration;

II. born in 1921-1945. When referring to the oldest generation, we deal with representatives of these years of birth. In rural areas, it is a group of people brought up in homogenous social and economic conditions. The informants from this interval are the main source of vocabulary related to the traditional organisation of rural life;

III. born in 1946-1970. The interlocutors from this generation grew up in different social and economic conditions, marked by gradual disappearance of the traditional rural structures and the conditions of traditional rural life. Their language has been largely affected by the school and human migration. Of importance is also the impact of the external factor - the unprecedented influence of the urban environment;

IV. born in 1971-1995. This generation is most diverse with respect to the conditions affecting their command of language. The social and economic transformations have left the deepest mark on them. The changes taking place in rural areas and brought about by external factors (including general electrification, water supply networks, different agricultural inputs etc.) which have contributed to a new reality, mainly on the vocabulary level;

V. born in 1996 and later. This generation grew up in the progressing transformation of the growth initiated by the previous generation. Observations of the language spoken by representatives of this generation lead to conclusions about the rate of linguistic changes that will take place in this group in the future.

\footnotetext{
${ }^{3}$ A case in point are submitted M.A. theses focusing on an analysis of vocabulary including thematic areas: TRADITIONAL CHORES OF RURAL WOMEN, HUMANS, WORK, THE FOREST. For comparison purposes, the same subjects are tackled in locations representing various dialects in Wielkopolska.
} 
The generational periodization adopted here slightly deviates from the divisions suggested by researchers into the (general) contemporary Polish language ${ }^{4}$ or dialects (Zagórski 1991, 9).

Let me emphasise the fact that this proposal is not based solely on the taxonomy of generations; the suggested division and the underlying rules prove very helpful in contemporary field research. Once the above presented generational division is adopted, long-term research can be carried out on the same informants and this is of great value in monographic projects. The Institute of Dialectology of the Poznań University is in possession of ample material representing all the identified generational groups ${ }^{5}$. Consequently, respecting the above assumptions provides insight into the dynamics of the changes taking place in the linguistic environment in the rural areas.

The transformations in contemporary rural areas lead also to including into the research individuals typically disregarded in this type of ventures. Bearing in mind the issues of the integration and disintegration of the language of villages (język mieszkańców wsi), we will also analyse utterances of extralocal populations well settled in the specific villages; the same holds true for representatives of various professions. Villages inhabited by exclusively rural populations or populations settled for several generations no longer exist; observations of the extralocals' linguistic behaviour is most useful in the context of describing linguistic contacts.

In order to provide more details, the material collected in accordance with the above general assumptions needs to be catalogued. The technical solutions available today allow to create registers in which each archived unit can be accompanied by very extended particulars. The technological progress leads to creating databases where the specific units may be accompanied by a very complex set of parameters. As a result, we can adopt additional methodological assumptions at the documentation stage.

The audio content is registered during field research and subjected to computer processing, preferably in the digital form.

The resulting database includes the following parameters:

A. the locations exceeding the name of the village - and possible allocation in the administrative division - will be based on the geographic coordinate system using strips and posts. The division of Poland, adopted by the Military Cartographic Works (Map), into 10 strips and ten posts, allows to locate material unambiguously irrespective of the changes to the administrative division. The map, published in the 1990s, allocates the longitude and latitude to any location under scrutiny. In the future, it will allow to present linguistic configurations in a visual form. It also provides insight into confirmations from any given fragment of an area. The goal is to have in a specific square several points providing material of diverse abundance. With duly ample documentation and a slight modification of the sizes of the fragments of the map it will be possible to make presentations based on the solutions applied in dialectrometric research (Goebl 1982; Kelle 2001; Müller 2001).

${ }^{4}$ Cf. the outline of "chronological succession of generations" as suggested in (Dubisz 1995, 83).

${ }^{5}$ Material obtained from kindergarten kids born in different years in rural areas is extremely interesting. It has been aptly reflected in an M.A. thesis written as part of my seminar (Kasprzyk 2001). 
B. The time of the recording including the day. We assume that the interviews with the same informants will be held in different time intervals, e.g. during a several days' long field trip or by an M.A. student working on a specific location. In special cases, research is repeated on the same informant. Data on the time of registering the dialectal material is of great importance in the context of defining the dialect as a language of the oral environment i.e. language facts, in this case communicated orally in a generation-based tradition.

C. The informant's initials; as a result, each language form can be associated with a specific individual. This is of importance because for monographs, several informants are selected. In the Institute of Dialectology of the Poznań University, we have recordings of sets of materials obtained in a specific location, typically from three to five individuals. Bearing this in mind, the corpora of texts obtained in Bukowiec Górny (Leszno county) and in Dąbrówka Wlkp. (Świebodzin county) are quite impressive. The former corpus includes more than 200 hours of recordings of conversations with more than 70 individuals. While some of the interlocutors were less outspoken, their participation was each time noted. While the corpus from Dąbrówka Wlkp. is smaller, its size exceeds that of typical sets of dialectal texts collected in a single village.

D. The basis of obtaining the material - we mark confirmations which are replies to the questions in the questionnaire or fragments of a casual conversation. Of special value are confirmations obtained in unofficial, spontaneous situations. The dedicated thematic questionnaires are some sort of a guide to a relatively informal conversation. In this situation, the interlocutors very frequently spontaneously confirm linguistic units loosely related to the subject of the conversation and not included in the questionnaire. The questionnaire is not presented during the conversation; the explorer needs to know its content as part of his/her preparations for field work.

E. Meta-language information provided by the interlocutors. The audio material often includes explanations of both the time when specific forms were used and the acceptability of use in a specific communication situation. These supplements are extremely valuable in the course of examining the dynamics of the linguistic changes taking place in rural areas. They are also the basis for identifying passive vocabulary.

$\mathrm{F} /$ generational identifiers - affiliation with one of the above presented generational groups but also the year of birth. The generationally diverse material superimposed on the map shows the direction and dynamics of the linguistic processes taking place in rural areas (Čižmárová 2000; Sierociuk 1996). The material, obtained in villages in accordance with these principles, coded in line with the adopted assumptions, poses an opportunity to view various processes taking place in the environment of a specific dialect. I have presented many such lists in my works (Sierociuk 2015). I will refer here to texts excerpted from a corpus from Bukowiec Górny; it pertains to variants of diminutives:

DRABKA [36 x]: DRABECZKA [12 x]: DRABINKA [20 x]:

$$
\begin{aligned}
& 2-\operatorname{SzM}(1886)--- \\
& 8-\operatorname{PaK}(1910)-1- \\
& --\operatorname{UrA}(1912)-5-
\end{aligned}
$$




$$
\begin{aligned}
& 1 \text { - PoJ (1919) - - - } \\
& \text { - - SoW (1920) - } 1 \text { - } \\
& 1-\operatorname{DoS}(1921)-- \\
& 1-\operatorname{MaF}(1922)--3 \\
& 1 \text { - SwS (1922) - } 1 \text { - } \\
& 1 \text { - SlJ (1923) - } 1 \text { - } \\
& 2 \text { - SzA (1923) - - } 2 \\
& \text { - - SzJ (1925) - - } 3 \\
& \text { - - PoW (1928) - - } 2 \\
& 4 \text { - SoA (1928) - - - } \\
& \text { - - SoF (1928) - - } 1 \\
& 1-\operatorname{LiE}(1935)-31 \\
& 3 \text { - PoB (1937) - - - } \\
& 4 \text { - PoC (1942) - - } 1 \\
& \text { - - GrP (1944) - - } 1 \\
& \text { - - GuB (1946) - - } 1 \\
& \text { - - BaK (1947) - - } 1 \\
& 7 \text { - SaZ (1948) - - } 2 \\
& \text { - - WoS (1959) - - } 2
\end{aligned}
$$

G/ negative confirmations i.e. confirmations that a specific unit is unknown (Sierociuk 1992); in the course of field exploration and in the resulting database they are treated as equal to text documentation.

The assumptions presented here in a brief form result in a methodological basis for very specific research into the structure and inner diversity of the language spoken in rural areas. The detailed techniques are direct derivatives of the above presented solutions; they are expanded on in a database structure developed with this research in mind*.

\section{Bibliography}

AJKLW (1979-2005), Atlas języka i kultury ludowej Wielkopolski, vol. I- VI, Z. Sobierajski, J. Burszta (eds.), vol. VII-XI, Z. Sobierajski (eds.), Wrocław-Warszawa-Kraków-GdańskŁódź-Poznań.

Čižmárová L. (2000), Jazykový atlas jihozápadní Moravy, Masarykova univerzita v Brné. Brno.

Dubisz S. (1995), Rozwój współczesnej polszczyzny, "Przegląd Humanistyczny" XXXIX, no. 5, Warszawa, pp. 69-88.

Goebl H. (1982), Dialektometrie. Prinzipien und Methoden des Einsatzes der Numerischen Taxonomie im Bereich der Dialektgeographie, Wien.

* It is a partly updated version of an article on Założenia metodologiczne badań języka wsi, "Poznańskie Spotkania Językoznawcze”, vol. XI, Z. Krążyńska, Z. Zagórski (eds.), Poznań 2003, pp. 131-136. 
Kasprzyk A. (2001), Język wiejskich dzieci przedszkolnych (Sulęcinek, gm. Krzykosy, pow. Środa Wlkp.). Poznań (an M.A. thesis written under the academic supervision of J. Sierociuk).

Kelle B. (2001), Zur Typologie der Dialekte in der deutschsprachigen Schweiz: Ein dialektometrischer Versuch, "Dialectologia et Geolinguistica" 9, pp. 9-34.

Mapa - Mapa topograficzna Polski, scale 1 : 200 000, Wojskowe Zakłady Kartograficzne.

Müller R. (2001), Rhenische Wortgeographie - dialektometrische Kartenauswertung, "Dialectologia et Geolinguistica" 9, pp. 35-53.

Sierociuk J. (1992), Oboczność podstaw słowotwórczych i poświadczenia negatywne w badaniach słowotwórstwa gwarowego, "Rozprawy Komisji Językowej Łódzkiego Towarzystwa Naukowego", vol. XXXI, pp. 169-181.

Sierociuk J. (1996), Budowa wybranych formacji rzeczownikowych - szczególnie nazw miejsc w gwarach między Wista a Wieprzem, Lublin.

Sierociuk J. (2015), Na ile w badaniach językowych można mówić o pokoleniu?, [in:] Dialog pokoleń w języku potocznym, w języku wsi i miast, w literaturze, w publicystyce, $w$ tekstach kultury, Elżbieta Wierzbicka-Piotrowska, Warszawa, pp. 41-50.

Skubalanka T. (1966), Stownictwo poezji miłosnej J. Słowackiego na tle tradycji, Toruń.

Zabrocki L. (1948), Archiwum Fonograficzne Instytutu Zachodniosłowiańskiego Uniwersytetu Poznańskiego, "Slavia Occidentalis" 19, Poznań 1948, pp. 515-517.

Zagórski Z. (1991), O mowie mieszkańców kilkunastu wsi wokót Konina, Wrocław-WarszawaKraków. 